\title{
THE DIFFICULTIES FACED BY STREET VENDORS AT THE BRASILIA CAPITAL FITNESS 2019 EVENT VENUE
}

\author{
Maria Dannielle Carvalho Correiaa; \\ Danielle Smilay de Almeida Rodrigues ${ }^{b}$; \\ Jozi Nei Silva Félix Barretoc
}

\begin{abstract}
The overall aim of this research paper is to identify the main difficulties faced by street vendors working around Brasília Capital Fitness, an event held in 2019 at the Pavilhão de Exposições do Parque da Cidade, a large events center in the city of Brasília, DF. A research questionnaire was specially designed for this research, aimed at the street vendors working at the event. The questionnaire sought to determine the socioeconomic profile of these workers, their main activities, and main difficulties they encountered when carrying out this work. The results showed that around $60 \%$ of the difficulties mentioned by the street vendors were related to inspections of their authorization to work at the event. It is noted that although $70 \%$ of the street vendors had authorization to work at the event, many of those inspecting their activities were too high-handed, creating barriers that prevented the street vendors from freely conducting their activities.
\end{abstract}

Palavras-chave

Entrepreneurship.

Street vendors.

Events. 


\section{INTRODUCTION}

In terms of entrepreneurship, Brazil is currently the second-best performing country worldwide, as reported by the GEM research (Global Entrepreneurship Monitor) published in 2017/2018, which compares forty-nine countries. According to another survey, two out of every five Brazilians aged between 18 and 64 years are either already running a business or have plans to do so. Yet, these Brazilians shown in the survey face great difficulties in realizing this dream of having their own businesses. One of these difficulties is the legal aspects required to start a business, which includes a lack of meaningful data on the Brazilian entrepreneur context.

As reported by Silveira, Teixeira \& Caixeta (2011), they found that there are many reasons why Brazil businesses do not become legalized. These include the high fees that need to be paid to the government authorities to legalize the business, a lack of knowledge on the field of interest, and limited skills and competence to manage the businesses costs, such as taxes. Legalizing these small businesses is therefore very complex, not only from a bureaucratic point of view of, but also financially, making difficult to formalize them. According to a study by Souza et al. (2014), the main motivation for street vendors starting their activity is not the search for a business opportunity, but to earn a living or add to their family income.

This research, therefore, presents a subject of current and social importance, as it seeks to understand the background of these self-employed entrepreneurs, and the difficulties they face to exercise their activities. And considering, it is a theme that has only a small number of researches on the academic field related to events.

In an initial approach to the subject, it became clear that these self-employed entrepreneurs face difficulties in conducting their activities. Therefore, the following research problem was established: What are the main difficulties faced by street vendors at events in Brasília?

Along these lines, the general goal of this research paper was to identify the main difficulties faced by these street vendors when conducting their activities. Its specific goals are characterize these entrepreneurs, in terms of their socioeconomic profile, and to describe the main activities carried out and the products they sell. The universe chosen for this study was Brasília Capital Fitness, an event held in 2019 at the Pavilhão de Exposições do Parque da Cidade, a large events center in the city of Brasília, DF.. The study subjects are street vendors working in the area immediately around the event venue.

\section{NOTIONS OF ENTREPERNEUSHIP}

For Tajra (2014), a person's attitude towards the daily situations and difficulties encountered, and how they deal with them, are all part of entrepreneurship. To be an entrepreneur is to be enthusiastic, and ready to amplify ideas and turn them into action.

As suggested by Salim and Silva (2010), entrepreneurship has been practiced since pre-historic times, when humans began to leave their homes to hunt and bring food to their families. Human beings have always searched for a better quality of life, throughout their existence, regardless of the situation. Although entrepreneurship nowadays is very different from that practiced in pre-historical times, its essence is still the same.

The idea of an enterprise emerges when there is observation and analysis of daily activities, trends, cultures, social habits and consumption. The creation of an enterprise is occasionally born out of aptitude, taste and other personal characteristics, even among those with no previous experience with this kind of activity (Bernardi, 2011).

Entrepreneurship is one of the vital drivers of the economy of our time (Santos \& Ferreira, 2017). When potential entrepreneurs have resources at their disposal and have developed skills, and when the country has a solid legal context that promotes entrepreneurship, and its registration is transparent, entrepreneurship rates tend to grow (Omri, 2020).

A study by GEM (2018), which includes fifty-three countries, making up $68 \%$ of the world population and $86 \%$ of the Global GDP, indicates that $38 \%$ of the Brazilian population - around 51.9 million people - either have a business or are currently creating one.

The survey shows an increase in the enthusiasm of Brazilians when I comes to starting their own business. Of thirteen topics listed as the "Brazilians' dream", there was a $15 \%$ increase in the desire to own a business; in $2017,18 \%$ of Brazilians had this desire, and by 2018 , it had risen to $33 \%$, occupying fourth place in the ranking, as shown in graph 1:

According to the survey, entrepreneurship in Brazil can separated into two categories: Entrepreneurship by opportunities and entrepreneurship by necessity.

Entrepreneurship by opportunity is when entrepreneurs open businesses having identified an opportunity in the market. Usually, this entrepreneur will make a business plan, study their competitors, and consequently, have a higher likelihood of surviving in their market. According to the GEM survey (2018), the number of entrepreneurs by opportunity has been increasing constantly since 2016, as illustrated in Graph 2:

On the other hand, entrepreneurs by necessity, according to Dornelas (2005), often started their businesses 
due to a lack of options, perhaps because they had lost their jobs, or due to a lack of other job opportunities. Generally, these individuals begin their informal activities without any previous planning. As a result, entrepreneurs by necessity generally do not create economic development. Their businesses often fail, which ends up increasing the statistics of failure of new companies.

Despite the constant increase in entrepreneurs by op-

Graph 01 - Brazilians' dream (2017 and 2018)

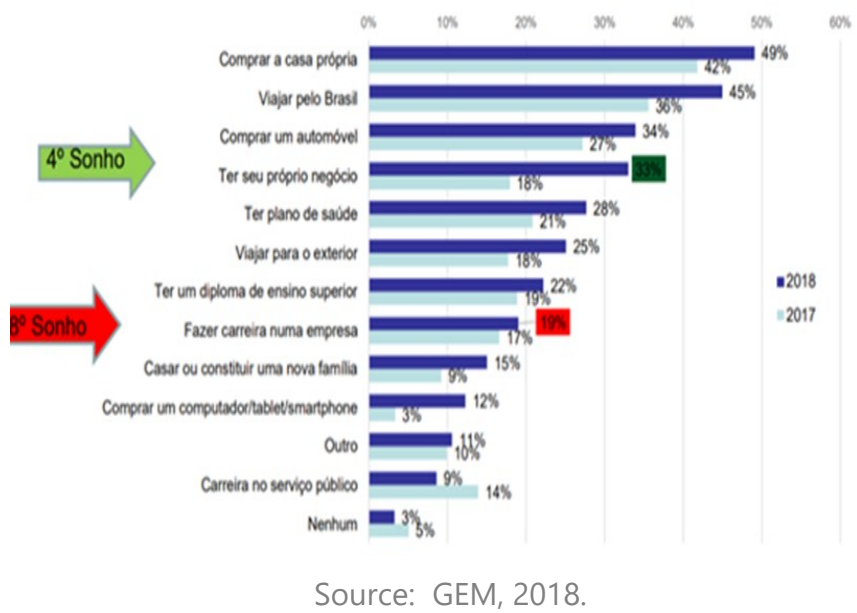

portunity, we cannot ignore the higher number of entrepreneurs by necessity, which make up around 38.2\% of the total, according to the GEM study (2018).

Economists have noted that entrepreneurs are essential to the process of economic development, and in their models, they take into account what society values, the individual behavior of its members being essential. In other words, there can be no economic development without entrepreneurial leaders at the foundation of society (Baggio \& Baggio, 2014).

The importance of an entrepreneurial spirit to the Brazilian economy is clear. The emergence of these sets of practices, which are capable of generating wealth and economic improvement for societies that support and practice them, is fundamental for social development.

Graph 01 - Motivation: "Opportunity" (2017 and 2018)

Em 2018, mantém-se a trajetória iniciada em 2016 de recuperação na proporçăo de Empreendedores Iniciais por oportunidade.

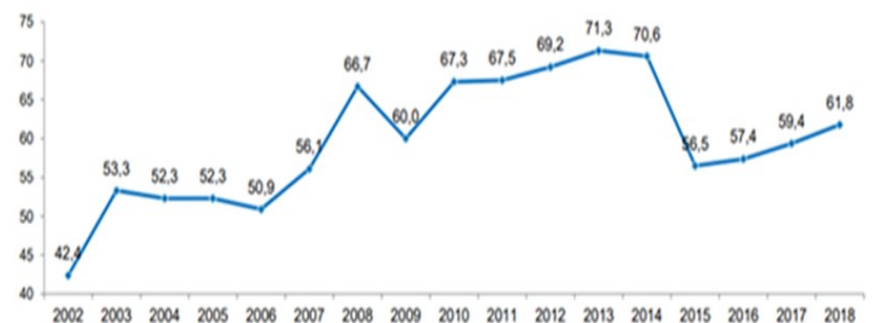

Source: GEM, 2018

\section{The profile of the entrepreneur}

Santos and Ferreira (2017) acknowledge that informal entrepreneurs represent a sector that generates Jobs and income for those who work in it. These businesses generally have low levels of organization and rare or non-existent division of labor.

Entrepreneurs, in essence, are people who have the aptitude to formulate and implement new ideas. They are willing to recognize and overcome risks; they are optimistic and have a good view of success. Instead of complaining about possible failures, they follow their own competences, and prefer to face the uncertainties of entrepreneurship than working for others. They seek independence. (Maximiniano,2011). Some of factors that influence and motivate entrepreneurs are listed in chart 1 :

The factors mentioned above are in agreement with the view of Cimar Azeredo, coordinator of work and the Instituto Brasileiro de Geografia e Estastística IBGE, given in an interview for Retratos magazine (2018, p.18). Azeredo states that since 2014, he has observed significant growth in the number of people who, after losing their formal jobs, decided to work as street vendors, particularly in the food sector, which linked to one of the personal factors shown in figure 1. Therefore, the personal factor of losing one's job was one of the most significant.

\section{Who are the street vendors}

According to Decree 39,769 of 11 April 2019, of Integrated System of Legal Norms of the Federal District, which regulates the activities of businesses or service provision by street vendors on roads, buses, subways, public parks and other public areas of the Federal District, a street vendor is defined as:

Art. 1 For the purposes of this Decree, any individual, civilly capable, who carries out a lawful activity of retail sale of goods, on his own account, on roads, buses, subways and public places in the Federal District, provided he has the necessary administrative and health authorization, for a predetermined term of validity, and having 2 years of electoral domicile in the Federal District. (2019, p.1)

It should be emphasized that the District legislation only views street vendors who have authorization from the appropriate public governing body as legitimate workers. However, it can be considered that a street vendor is not necessarily a person who is working illegally, but one who is conducting an activity that is permitted, seeing to generate a minimum 
income for his or her survival, or due to a lack of opportunities in the conventional job market.

Chart 01 - Factors that influence and motivate entrepreneurs

\begin{tabular}{l|l}
\hline Personal factors & $\begin{array}{l}\text { Desire for personal fulfillment, job dissatis- } \\
\text { faction, desire to make money, passionate } \\
\text { desire to change their lives, or losing a job. }\end{array}$ \\
\hline $\begin{array}{l}\text { Environmental } \\
\text { factors }\end{array}$ & $\begin{array}{l}\text { Analyzes and identifies business opportu- } \\
\text { nities or an opportunity to be involved in a } \\
\text { project. }\end{array}$ \\
\hline $\begin{array}{l}\text { Sociological } \\
\text { factors }\end{array}$ & $\begin{array}{l}\text { Possibility of having a group of competent } \\
\text { people with similar characteristics, influ- } \\
\text { ence of parents or models that have al- } \\
\text { ready been developed in the family. }\end{array}$ \\
\hline
\end{tabular}

Source: Based on Baggio \& Baggio (2014, p.33).

Another relevant factor in the context of the activities exercised by the informal entrepreneurs is that, in emerging economies like Brazil, effective regulation of the economy, concrete laws, reducing bureaucratic obstacles, and implementing favorable policies are all factors that provide incentive for entrepreneurs to seek to formalize their activities. (OMRI, 2020).

Data from the IBGE, published in Retratos Magazine (2018, p.18), shows that in the 3rd half of 2017, there were around 1.3 million street vendors in Brazil, with 501,3 thousand in the food sector alone.

To understand the formalization of small entrepreneurs in Brazil, it is necessary to understand the image of the Micro individual entrepreneur- MEl, the formalized modality of a company created with the goal of legalizing and consequently bringing intrinsic benefits, such as pension plans and loans for investments, among other aspects, to many professionals who are practicing their activities illegally in this country.

According to the Portal do Empreendedor website (2020), the main source of information on the MEl, in order to participate in this modality, the small entrepreneur needs to:

a) Have an annual profit of $R \$ 81,000.00$ per year

b) Never have participated as an associate of any business.

c) Hire not more than one employee.

d) Conduct an economic activity that is covered by Annex XI of CGSN resolution 140 of 2018, in regard to all activities that the MEl is permitted to carry out.

Thus, according to the Portal do Empreendedor website (2020), the MEI is a method that creates a formal business, in other words, it is an entrepreneurial application that regularizes, with the government bodies, the status of a person who conducts an economic activity.

\section{Brasília Capital Fitness 2019}

According to the official Facebook page of Brasilia Capital Fitness (2009), this is the largest event in Brazil focused on fitness, health, wellness, and quality of life. Its purpose is to inform society to the importance of good life habits; it encourages the practice of physical activities and it gives tips and information about wellness, health and longevity. This study focuses on the 24th edition of the event, which was held at the Pavilhão de Exposições do Parque da Cidade, from 3rd to 6th October 2019.

The event has an extensive program, and several technological innovations, including talks and workshops in the areas of Physical Education, Health quality, nutrition, wellness, business and longevity. It also includes competitions, games, dances and a fair selling fitness, sport and nutritional products.

It has more than sixty attractions and one hundred and twenty-eight exhibitors, with an estimated public of approximately a hundred thousand people during the four days of event. According to Fábio Padilha, CEO of Brasilia Capital Fitness: "The goal of the producers of the event is to promote the fitness market and the production chain as a whole." (Magalhães, 2019).

According to the Secretaria Executiva das Cidades (2019), to obtain authorization to work at BCF, it was necessary to comply with the Buriti Palace Annex, fill out a formal petition, and the draw was carried out and only after the petition was delivered to the authorities. Street vendors without up-to-date formal status with the Federal authorities were obliged to provide a $3 \times 4$ photo, social security card (CPF), and a proof of residence. For Brasilia Capital Fitness, the government issued thirty authorizations - fifteen for booths and fifteen for clerks.

\section{METHODOLOGY}

This study uses the quantitative method which, according to Gatti (2004), involves numerical or conceptual interpretation of facts, events, and phenomena. The goal is that this translation has a level of rational legitimacy, theory, as compared to the development of the facts.

This research was descriptive and exploratory; it focuses on preliminary observation of street vendors in the context of the external area of the Pavilhão de Exposições in the city park of Brasilia, who set up their stalls around the entrances and exits of the event. These places were chosen because that is where most 
of the street business is concentrated, and these are places with a higher flow of people participating in the event is. The selection of this sector allowed a more general and complete view of the types of food offered by the street vendors and their interactions with the environment. Based on the dialogues with these street vendors, testimonies and observations were gathered.

It is worth observing that this research is limited to a specific time range and geographic space. Thus, the subjects of this research were street vendors, working in the areas surrounding the BCF event venue. A survey of the number of street vendors working in this area found an estimated total of 25 street vendors/selfemployed workers, and of this sample, the aim was to interview at least 23. However, only 20 of these street vendors were present at the event, 18 of whom agreed to answer the survey questionnaire.

Initially, a bibliographic investigation was carried out on the subject of entrepreneurship and its general aspects. Based on the definitions found, and the way in which the investigation is characterized, a more specific study was conducted on the difficulties found by these entrepreneurs when conducting their activities. In the bibliographic survey, we looked for academic articles on entrepreneurship, street vendors and entrepreneurs. Concerning the difficulties encountered by the entrepreneurs, we found that each difficulty has its particularities, contributing in different ways to a broader analysis.

Finally, we performed a field study in which we applied a research tool with the street vendors working in the area around the event venue. This tool was a structured closed questionnaire, the aim of which was to collect socioeconomic data from the workers, including their legal status as self- employed entrepreneurs, as well as identify any difficulties they found and characterize their activities.

The first part of the questionnaire included questions designed to identify where the street vendor was interviewed and the kind of activity performed, without identifying the person being interviewed. The second part included questions designed to elicit socioeconomic data on the street vendors.

The survey was implemented in the form of interviews, as follows: First, the street vendors were observed at their work place, in order to study the rhythm of their work and the routines of each one. Next, an informal dialogue was initiated, seeking to foster a relationship of trust with them. The research was then presented to the vendors, telling them what it was about, the students involved and the institution they belonged to, and asking the vendors if they would agree to answer some questions.

The website QuestionPro was used to extract the results of the questionnaires and arrange them in the form of tables. Graphs were produced using Excel soft- ware. The analyses were carried out using quantitative and descriptive methods.

\section{DISCUSSION AND RESULTS}

All the analyses of this research were performed using the quantitative method; this research was based on the tabulated interview results, immediately after their application. Based on this information, it was possible to identify the profile of the interviewees, as detailed below.

\section{Socioeconomic Profile of the street vendors}

The survey served as a basis to describe some of the socioeconomic aspects of the street vendors, such as sex, age, ethnic group, level of income, and level of education. The socioeconomic characteristics are analyzed descriptively in graph 3 , which presents the profiles and the percentages of each aspect:

The analysis of socioeconomic characteristics of the interviewees shows that $44.44 \%$ were aged between 40 and 50 years, followed by $27.78 \%$ aged between 30 and 40 years. This fact supports the assertion of Pamplona (2013), that there is a significant percentage of street vendors who are more mature in age (older than 40 years old). His study also points out that older the informal workers, the less likely they are to have a formal wage.

In regard to Family monthly income, $50 \%$ of those surveyed said their monthly income ranged between $R \$ 998.00$ and $R \$ 1,196.00$, while only $16.67 \%$ had monthly incomes higher than $\mathrm{R} \$ 4,999.00$. For Pamplona (2013), street vendors usually belongs to poor families, with limited opportunities to get the qualifications needed to find a formal job, since education of this type costs money.

In terms of level of education, $33.33 \%$ of the respondents had a High School diploma and $67 \%$ had not completed elementary school. According to Bernardes (2011), without reaching job Market inclusion, people begin working on underemployment, occupying a good part of their time, making it more difficult for them to continue their studies. Consequently a fraction of this population is illiterate or has very poor education. For the sociodemographic variable sex, the data sample shows a balance between males and females, with $50 \%$ $\%$ of each. This corroborates the GEM (2018) study, in which the proportion of women entrepreneurs at an early stage of the development of their business was around $50 \%$. 
In regard to race, the majority of the respondents, about 66, $67 \%$ considered themselves to be Parda (meaning Brown, or Mixed Race). The data is in accordance with the racial self- declaration survey of the Brazilian population, produced by the Pesquisa Nacional por Amostra de Domicílios Contínua (Continuous National Household Sample Survey) - PNAD, which indicates that $46.5 \%$ of the Brazilian population declares itself to be Brown. Black and Brown skinned people make up $56 \%$ of the total population, yet these individuals are still at a disadvantage in the job market compared to Whites, a discrepancy that is also reflected in income, education, housing and other aspects (IBGE, 2019).

Another aspect investigated in the survey was the number of street vendors registered as the MEls (Individual Micro-Entrepreneurs). The survey found that around $77.78 \%$ of the respondents were registered. This is an indicator of formality, bearing in mind that this is a very informal environment, and that this type of registration is not essential for the type of work being carried out. This aspect is shown in Graph 4:

According to Oliveira \& Forte (2014), the formalization of these enterprises is due to the benefits of registering as an MEl, as self-employed workers are seeing that this provides an opportunity to grow in their business with greater security.

It is concluded that the majority of street vendors working at the event were formalized, i.e. they could not be viewed as a population that is working illegally or informally. The vendors that registered did so to support their families. Only $22.22 \%$ of the vendors did not have MEl status.

For those who did not choose the formalization route, it must be considered that the economic activities receive legitimate recognition from the parties that deal directly with them, such as the customers, suppliers and employees, if there is any (Webb et al., 2009).

Moreover, the existing informal entrepreneurs can better understand the improvements on the quality of the national governance which can hamper informal activities, given them incentives to formalize their businesses (Omri, 2020).

\section{Activities of the street vendors}

This topic characterizes the activities carried out by the street vendors at the BCF, as well as the number of customers served each day, the average amount spent by each customer at the vendors' stalls, the main products offered, and the amount of time spent working in the area (graph 5).

Regarding the time of spent working in the area, it was observed that $58.82 \%$ of the street vendors had wor-
Graph 03 - Socioeconomic profile of the street vendors

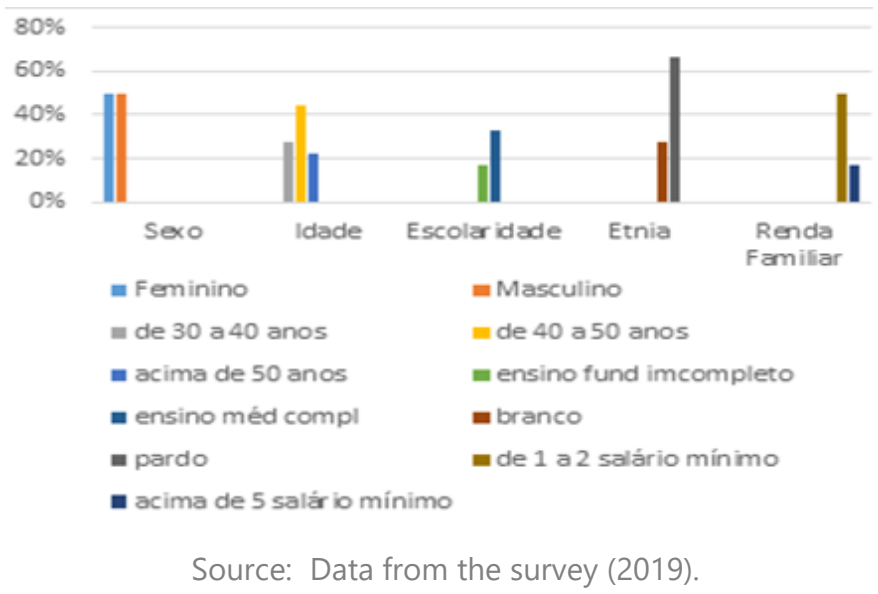

ked on that area for more than 10 years, showing broad experience in the area, while $17.65 \%$ had spent around 1 to 3 years working in the area. These figures are illustrated in Graph 6:

Graph 6 shows that the majority of vendors at the event sold food and drinks. These included barbecue (18.78\%), hot dogs (16.67\%), hamburgers (16.67\%) and various kinds of beverages (29.17\%). The data corroborates the findings of Saraiva et. al (2018), who state that almost $50 \%$ of the street vendors in Brazil are working in the food and drink sector.

In regard to the average number of people served by the street vendors working at the event, the figures are shown in Graph 7 below.

The operating hours of the event were from 8:00 am to $6 \mathrm{pm}$. This meant the street vendors worked approximately 9 hours a day. The majority (around 66.76\%) served between 30 to 100 customers per day. Another $38,98 \%$ served an average of 50 to 100 people per event day. The majority of these customers (61.11\%) spent around $\mathrm{R} \$ 10.00$ to $\mathrm{R} \$ 20,00$ Brazilian reals on products at the stall.

The average amount sold by the vendors interviewed is shown in Graph 8:

During the event, just under $70 \%$ of the street vendors sold between $\mathrm{R} \$ 100$ and $\mathrm{R} \$ 1000$ reals. Of these, $33.33 \%$ sold between $\mathrm{R} \$ 100$ and $\mathrm{R} \$ 500$ reals, and another $33.3 \%$ sold between $\mathrm{R} \$ 500$ and $\mathrm{R} \$ 1000$ reals.

\section{Difficulties encountered}

The majority of the difficulties encountered by the street vendors were related to:

- Inspections - Around $57.89 \%$ said that one of 
the main difficulties that they faced was the inspectors working at the event. This does not imply that the vendors were unauthorized, as $67.67 \%$ had government permits to work in the area immediately around the venue. According to vendors, the main major issue was the lack of respect and high-handed attitude of the inspectors, whether stipulated an area that does not favor sales, as it is far from public circulation. In other circumstances preventing vendor larger stalls to occupy the necessary space, despite the great quantity of equipment that these vendors needed to perform their activities. There were occasions when the vendors were barred from entering the venue with their vehicles to set up their stalls, and were obliged to park further away and carry their equipment on foot.

- $\quad$ Lack of infrastructure - Another difficulty that had a significant impact on these vendors was the lack of basic infrastructure around the venue. Around $26.32 \%$ of the vendors claimed that they paid taxes to the government to be able to work, but when they arrived at the venue, they found a lack of even the basic infrastructure; they complained of a lack of lack of restrooms, power connectors, and water supply.

- $\quad$ Event producers - Around $10.53 \%$ mentioned Graph 04 - MEl Registration or formalization

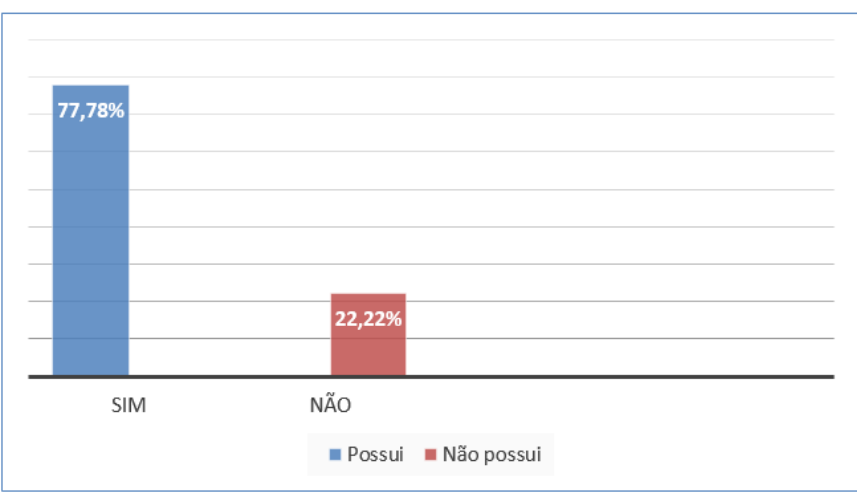

Source: Data from the survey (2019).

that the event producers made it difficult for the public to access the street vendors, by installing bars and fences.

Despite the difficulties, the reasons that led these street vendors choose that event were: the high estimated public $(45.5 \%)$, and the fact that they had sold there at previous events $(22.73 \%)$. They were pleased with their decision, stating that in previous editions, the public had been high, with a high volume of sales at their stalls.

Around $66.67 \%$ had authorization to work at the event; of these, all had a permit from the City Secretary Office.
When asked about what could be done to improve the practice of their activities, around $89.74 \%$ said regulation, and making their trade a legal profession. A study conducted by Gomes, Freitas and Júnior (2005) states that it is necessary to support and encourage these activities through new investments, because even though these entrepreneurs have the necessary characteristics of an entrepreneur profile, the environment in which they are involved, the resources available and the institutional activities created are not satisfactory.

One of the difficulties found in conducting the interviews was the lack of procedures to facilitate this discussion with the street vendors without disturbing their selling routines. Bearing in mind that the vendors were setting up equipment or serving customers while responding the survey, taking up much of their attention, this was a hindrance to the research. In a few cases, the vendors refused to respond to the questionnaire as they were too busy.

It is therefore clear that street vendors are not people who prefer the informality, they seek to work according to the regulations. However, the various issues found when it comes formalizing their businesses made it difficult for them to legalize the work.

It is important to highlight that those that are not formalized are seen by their group of interest, because none of them are engaging an antisocial or immoral activity. (Webb et. al, 2009), (Santos \& Ferreira, 2017).

Graph 05 - Time working in the area

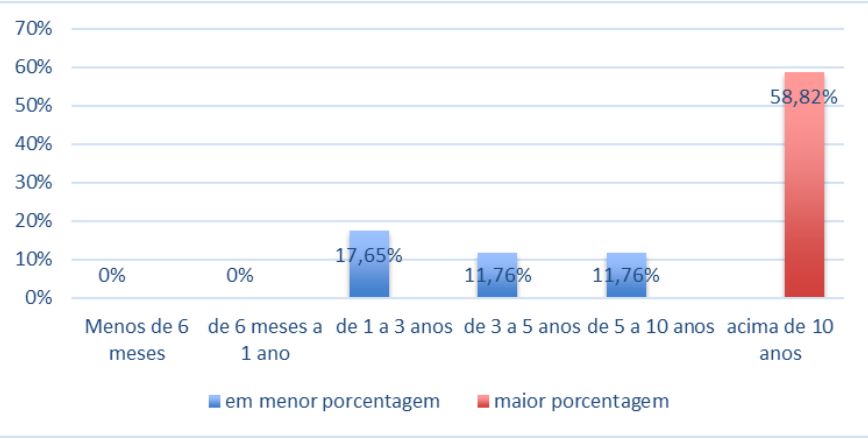

Source: Data from the survey (2019)

Ideally, the government should create and implement policies to encourage entrepreneurship, reducing taxes for small businesses and making the legislation in this area less restrictive. There is also a need for more teaching programs for entrepreneurship, seeking to extend the level of education from basic (primary school) level through the offer of programs through to higher levels (Graduate degrees) (GEM, 2018).

\section{FINAL CONSIDERATIONS}

This study highlights that street vendors have characteristics that are consistent with the profile entrepre- 
Graph 06 - Products explored by the vendors

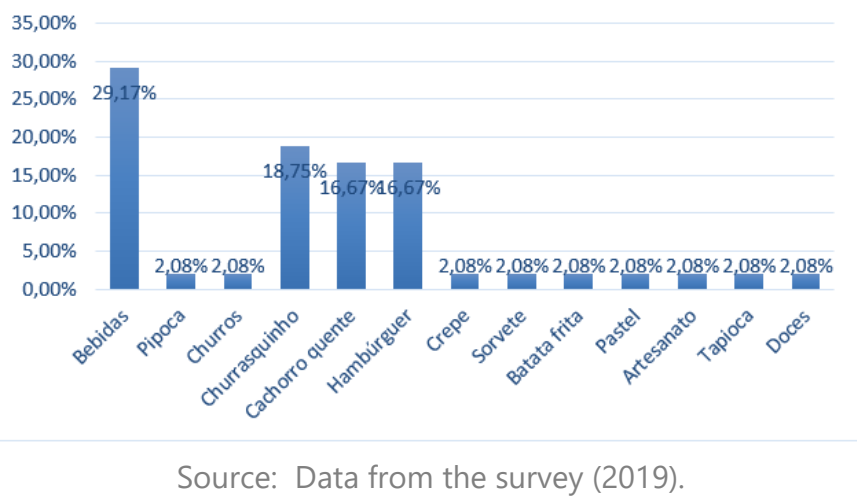

neurs; however their working environment and business opportunities are inadequate when compared to those of other business enterprises.

That, because it could be seen that the street business is a source of support money to many people, who presented characteristics as: Higher age, low education level, monthly income relatively low in a competitive job market. These factors favor the introduction of these people to work as street vendors in events.

However, not all street vendors work informally; many of them adhere to government policies, are legalized, and benefit from some of the rights and privileges this brings. Information that emphasizes the fact that, governmental action regarding the entrepreneurial context

\section{Graph 07 - Average number of people served}

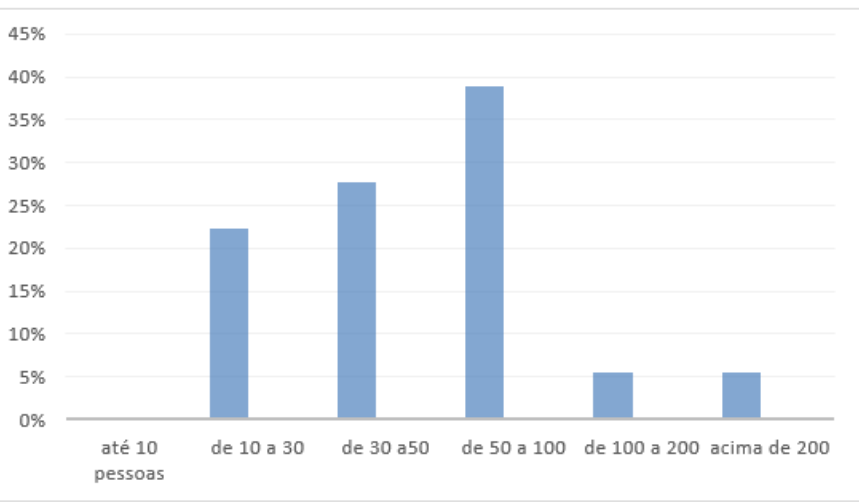

Source: Data from the survey (2019).

is a major driver to more activities and guarantees.

One of the overall aims of this research paper that was to identify the difficulties that street vendors face in performing their activities. It was found that highhanded treatment given by the inspectors was the main source of difficulties and dissatisfaction.

This research paper offers some initial ideas aimed at prompting further study on the activities of street vendors at major events venues. It raises some reflections and identifies the main difficulties faced by the street vendors. A suggestion for further study would be to focus on the inspections, who performs them, and how these processes are done. Another area for research would be the legal status of the street vendors, the

Graph 08 - Average amount sold at the event

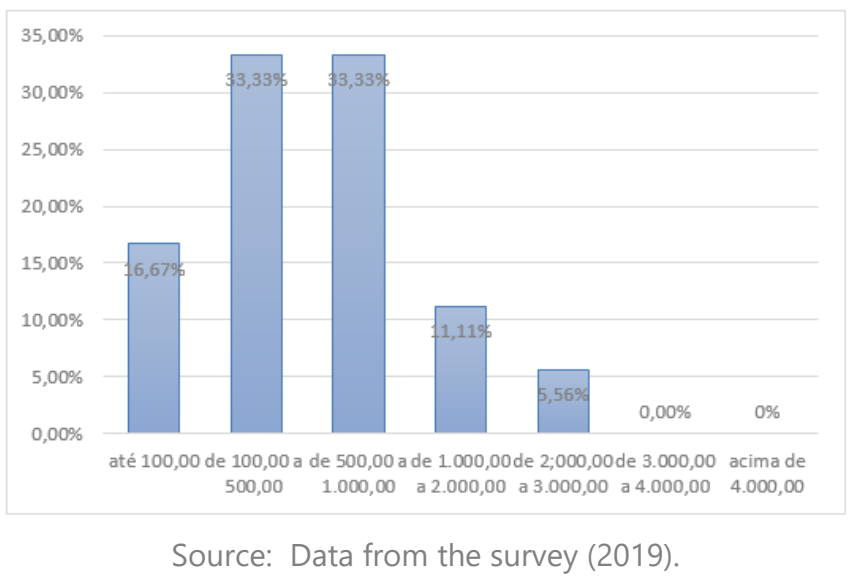

benefits they see in becoming regularized, and the reasons why many of them do not seek this permit. The research could also be extended to the different areas and contexts where the street vendors work, in order to develop a better understanding of the subject, in the context of the production chain of events in Brazil.

\section{REFERENCES}

BAGGIO, A. F. \& BAGGIO, D. K.; (2014) Empreendedorismo conceitos e definições. Revista de Empreendedorismo, Inovação e Tecnologia, IMED.

BERNARDES, J. F. (2011) COMÉRCIO INFORMAL NA ÁREA CENTRAL DE MANAUS: de ambulantes a camelôs, de camelôs a empreendedores autônomos. Universidade de Brasília Faculdade de Economia, Administração, Contabilidade e Ciências da Informação e Documentação, Departamento de Administração, Brasília, Brasil.

BERNARDI, L. A. (2011) Manual de Empreendedorismo e Gestão, Fundamentos Estratégias e Dinâmicas. São Paulo: Atlas.

Capital Fitness (2019) Sobre o Brasília Capital Fitness. Brasília: facebook, Available at https://www.facebook.com/ CapitalFitnessOnline/ on Oct 2019.

DECRETO № 39.769, DE 11 de abril de 2019. (2019, 11 abril) Sistema Integrado de Normas Jurídicas do Distrito Federal, SINJDF e artigo 34 da Lei no 6.190, de 20 de julho de 2018. Lei Orgânica do Distrito Federal.

DORNELAS, J. C. A. (2005) Transformando ideias em negócios (2 $\stackrel{a}{a}$ ed.) Rio de Janeiro: Elsevier.

GATTI, B. A. (2004) Estudos quantitativos em educação. Fundação Carlos Chagas. Educação e Pesquisa, São Paulo.

GEM, Global Enterpreneuship Monitor (2018) GEM Brasil 2018. Available at 
https://datasebrae.com.br/wp-content/uploads/2019/02/GEM2018-Apresenta\%C3\%A7\%C3\%A3o-SEBRAE-Final-slide.pdf on Oct 2019.

GOMES, J. A.; FREITAS, A. A. F. \& CAPELO JÚNIOR, E. (2005) Retrato do Empreendedor Informal. in: XXV Encontro Nac. de Eng. de Produção. Porto Alegre.

IBGE, Instituto Brasileiro de Geografia e Estatística. (2019) Desigualdades sociais por cor ou raça no Brasil. Available at https://biblioteca.ibge.gov.br/visualizacao/livros/ liv101681 informativo.pdf. on Apr 2020.

MAGALHÃES, C. (2019) Brasília Capital Fitness 2019, terá oportunidades de ampliar negócios e criar bons hábitos de vida. Correio Braziliense. Disponivel em: https:// www.correiobraziliense.com.br/app/noticia/comunidadeei/2019/10/02/noticias-comunidadeei,793935/brasiliacapital-fitness-2019-tera-oportunidades-de-ampliarnegocios-e.shtml Acesso em: Outubro, 2019.

MAXIMIANO, A. C. A. (2011) Administração para Empreendedores. (2a ed.) São Paulo: Pearson Prentice Hall.

OLIVEIRA, O. V.; FORTE S. H. A. C, (2014) Microempreendedor Individual: Fatores Da Informalidade. CONNEXIO Revista Científica da Escola de Gestão de Negócios. Universidade Potiguar.

OMRI, A. (2020) Formal versus informal entrepreneurship in emerging economies: The roles of governance and the financial sector. Journal of Business Research. 108, 277-290.

PAMPLONA, J. B. (2013) Mercado de trabalho, informalidade e comércio ambulante em São Paulo. Revista Brasileira de Estudos de População. Rio de Janeiro, 30 (1), 225-249.

PORTAL DO EMPREENDEDOR (2020) MEI, Micro Empreendedor Individual. Brasilia. Available at http:/ www.portaldoempreendedor.gov.br/duvidas-frequentes. on Apr 2020.

SALIM, C. S. \& SILVA, N. C.; (2010) Introdução ao Empreendedorismo: Construindo uma atitude empreendedora. Rio de Janeiro: Elsevier

SANTOS, E. M. M. N. \& FERREIRA, J. J. (2017) Analyzing informal enterpreneurship: a bibliometric survey. Journal of Developmental Entrepreneurship. 22 (4), 1-20.

SARAIVA, A.; SANTOS, L.; BOING, M. \& MARTINS, R. (2018) De sol a sol. Retratos. Rio de Janeiro, RJ: IBGE. n. 10, p. 17-21, Abr., 2018. Available at https:// agenciadenoticias.ibge.gov.br/media/com_mediaibge/ arquivos/bc63183b37080b9b1c5db0af4cb631f7.pdf on Oct 2019.

SECRETARIA EXECUTIVA DAS CIDADES. Ambulantes podem preencher o requerimento para trabalhar no Capital Fitness e Só Track Boa. Available at http://www.cidades.df.gov.br/ ambulantes-podem-preencher-o-requerimento-paratrabalhar-no-capital-fitnesse-e-so-track-boa/ on Oct 2019.

SILVEIRA, J. P.; CASTRO, T. M. R. \& CAIXETA, R. P. (2011) Empreendedor Individual: Oportunidades e Desafios Pós Formalização. in: IV Seminário de Administração e II Seminário de Contabilidade I Mostra Científica. Rio Paranaíba MG.
SOUZA, R. S.; SILVEIRA, A.; NASCIMENTO, S. \& ESPIRÍTO SANTO, M. O. (2014) Vendedores Ambulantes e o Modelo de CAIRD (1991): Tendência Empreendedora Geral (TEG). VIII Encontro de Estudo e Empreendedorismo e Gestão de Pequenas Empresas (EGEP); Goiânia.

TAJRA, S. F. (2014) Empreendedorismo: Conceitos e práticas inovadoras. São Paulo: Érica/Saraiva.

WEBB, J.W.; TIHANYI, L.; Ireland, R. D. \& Sirmon, D.G. (2009) You say illegal, I say legitimate: Entrepreneurship in the informal economy. Academy of Management Review, 34(3), 492 -510 . 
